\title{
Insights on Educational Programs at The University of lowa Museum of Art Jeungmin Noe
}

On the Sunday of April 5th, many people are heading to the University of lowa Museum of Art. Inside the museum, there is much excitement. There are the opening reception and lecture on the "Victorian Fairy Paintings." In the center of the Sculpture Garden, which is a sunken space filled with sculptures and murals, there is an enormous decorative piece which symbolizes a fairy woodland. The woodland is filled with many flowers made from coffee filters dyed different colors, birds, twigs for representing real woodlands, and tiny lights linked and strung together. At the dessert table beside the woodland a man piles up a plate with different kinds of cookies.

In the Lazansky room on the other side of the museum, people are gathering to hear the lecture on the fairy exhibit. Many are not able to find seats, so the guest speaker decides to do an additional lecture later in the afternoon. Emily, the Curator of Education, is busy talking to Mary, who has worked on the central decorative piece. Mary (a pseudonym) has been working as a docent for years and volunteered to do the decoration with two other docents. Without them, Emily couldn't have completed the preparation for this reception. Later that day, Emily and Pam are informed that over 1,000 people had come to the museum. The next day, in the staff meeting, everyone celebrates such a successful beginning again.

The reception shows many features of how a local museum is working in a changing environment. Museums are no longer a place where beautiful masterpieces from the past are displayed on walls. Today museums try to provide programs for diverse groups of people, and are beginning to compete with other kinds of institutions which provide culturally or intellectually-rich experiences. Hence, museums are beginning to have more culturally oriented programs for school students, community leaders, ethnic groups, seniors, disabled people and any other kind of group or individual. Particularly, the focus on families is increasing, because families and societies are demanding more chance to spend time together and be culturally nurtured. Programs like "family day" or "Sunday exhibit openings" are getting more popular in communities. The Goals 2000: Educate America Act supports parents' participation in such programs in order to expose their children to cultural and educational environment ( $p 19)$.

As Weil (1990) stated, the functions of museums are to preserve, to study and to communicate. The value of people's participation and interactions with collections is highlighted. People want to have experiences at museums beyond merely looking at collections. This change has encouraged museums to pay more attention to visitors and their relationship to exhibits. Consequently, museums are increasing the number and quality of their educational programs. Here, I will discuss how the educational mission of American museums has been shaped through history and how a museum achieves its goal through implementing a 
series of 3rd graders' tours. While I describe the programs, issues related to docents who guide the tours, are stated in many aspects: how they are trained, how they implement the tours, what they contribute to the museum. I had interviews with docents and with the Education Program Coordinator and observed tours, docents' training sessions, and staff meetings of the museum.

\section{History of Museums and Museum Education}

In order to understand the trends in American museum education, a brief history of museums is discussed. In America, the first public museum was opened by the painter, Charles W. Peale, in Philadelphia in 1786 (Hamilton, p. 101). The museum had his own works and collection of natural wonders. In the 1870s and 1880s major museums opened: the Metropolitan Museum of Art and the Museum of Fine Arts in Boston, 1870; and the Art Institute of Chicago, 1879 (Taylor, J.). In 1870, the Massachusetts Legislature created a corporation "for the purpose of erecting a museum for the preservation and exhibition of works of art, of making, maintaining and establishing collections of such works, and of affording instruction in the Fine Arts" (Hamilton 107). This demonstrates that one of the objectives of the museums was to educate.

The Boston museum provided systematic instruction to the students of the School of the Museum of Fine Arts, and the Metropolitan Museum of Art had a program for the general public. However, the programs were still limited to well-educated people. Early museums in America were not able to provide significant learning opportunities until the turn of the century. Visitors had a hard time grasping any meaning from the exhibits.

In the early twentieth century in the United States, museums began to emphasize their educational mission, once they had established the majority of their collections (Rawlins 6). There were a variety of programs including school and adult trips, special events, lectures, classes, publications and outreach kits for schools (IMS, p. 29). These programs were initiated by two museum professionals who expanded the potential of public education programs at museums. One was John Cotton Dana of the Newark Museum and the other was Henry Kent at the Metropolitan Museum of Art (Rawlins 7). At the Newark Museum, Dana organized exhibitions and established a lecture series, art classes, and an apprenticeship program for the general public and for school use from 1909 (Dobbs 39-41).

On the other hand, Kent believed in "art for the people's sake" (Dobbs). He expanded the educational programs of the Metropolitan Museum of Art, including gallery lectures, Saturday morning storytelling, a slide library, publications, programs for schools, traveling exhibits, films, and radio broadcasts (Rawlins 7). He reached various kinds of groups, including handicapped children, by providing multiple-dimensional programs. These two exceptional museum professionals, Dana and Kent, enabled their museums to connect with schools and to have many tours in the galleries. Thus, many more people became welcome in those museums. However, other museums were not the same, since the goals of the museums were not as clearly defined. 
The economic depression of the 1930s provided a new phase of development in American museums. Museums put great emphasis on their educational mission in order to get more public funds, when there were fewer private donations to museums (Rawlins 8). During the time between the World Wars, emphasis was put on artists rather than the objects themselves. People enjoyed listening to an artist's personal story more than to the story of a painting or a sculpture. More people attended lectures and gallery tours (Wittlin 152). An expanded transportation system also allowed more people to visit museums (Glaser 9). Some museums put the collections on loan to schools or organizations. In this period of time, temporary loans were made between museums (Wittlin 152) and collections were made available to schools, libraries, associations, or even individuals.

Between 1945 and 1970, ever-increasing numbers of museums were founded and more education programs were provided. In particular, more art museums were built. The Association of American Museums reported in 1961 that 79 percent of museums were providing planned educational programs, which was almost five times the percentage in 1932. Financially, museums received some benefits from policy changes. The Tax Reform Act of 1969 allowed museums to receive more financial support from donors, as educational and non-profit organizations (McGrath). When the National Endowment for the Arts began to provide grants in 1969, it encouraged museums to expand their education programs; as a result museums considered their educational function more seriously than before (Turner).

The quality of education programs became an important issue.

Cooperation between museum staffs and psychologists resulted in an increasing emphasis on visual cognition, learning, and human communication (Wittlin 180). The evaluation of museum works also became an important research subject (Eisner and Dobbs. The Uncertain Profession).

In the late twentieth century, the cultural contents of exhibits or education programs have become the subject of discussion. Issues like multiculturalism and pluralism have been raised among museums, in the art world and, and in art education. Cultural diversity is one of the primary influences on museums.

The paradigm shift from positivism to post-modernism and other new ideologies has also contributed to dramatic changes in society and consequently in museum. People certainly agreed that museums couldn't fix current social problems. However, at the same time, people admitted cultural organizations like museums could play a role in improving the quality of communities and easing the emotional barriers among community members (Museums in the Life of a City, p11-12). Many art educators are concerned more than before, because art education programs in America are not supported as much as they were. Many elementary students don't have art teachers, and secondary students rarely have art classes. Ironically, museums have become more popular than before because some schools think they can substitute museum visits for art classes. 
The educational function of museums is also being redefined, and approaches to education are being reconstructed. In 1987, a definition of art museum education emerged from the meeting of twenty-three museum educators representing the Museum Division of the National Art Education Association and the Education Committee of the American Association of Museums. The following is what they agreed upon as stated by Pittman-Gells: "Art museums function as educational institutions by presenting original works of art and by making these primary resources accessible to broad audiences. The purpose of art museum education becomes to enhance the visitor's ability to understand and appreciate original works of art and to transfer these experiences into other aspects of the visitor's lives" (Mayer 17). This statement demonstrates museums' concerns about how their education affects visitors and enriches personal experience. Museum visitors are expected to relate their/knowledge and their personal experience to the exhibited objects. The objects do not read their physical attributes, but the contexts and stories behind the objects. Many exhibitions are organized in thematic approaches now, compared to the chronological approaches before. Concepts of the "meaning" of objects, and the way museums communicate about them, are changing (Excellence and Equity, p. 30). The context and significance of the objects are being interpreted.

\section{Education Programs in an Art Museum}

Museums have contributed to promoting art education since the late nineteenth century. Implementing education programs becomes more important in the late twentieth century. Among the education programs in art museums, the school group visit is often the most important program in many museums. Each year millions of school children participate in education programs at art museums. The findings from research show that many students take the experience as a positive and interactive learning process (Gottfried, p. 173). Schools and museums have been building a strong relationship and working together for creating meaningful learning experiences.

The University of lowa Museum of Art has a special field trip month every year. This program is called "WOW," which stands for "Widen Our World." It is a curricula-based program which the local school district and the museum have collaborated to develop. For eight years it has attempted to bring all local thirdgraders, about 1000 students. A local bank and a construction company support the program. This year, 965 third graders from 20 schools plan to visit the museum. The program includes multiple strategies for educating teachers and students. Before the visits, teacher in-service training is provided. For the students, the Curator of Education organizes pre-visit materials, such as slides about the collections and some written materials, which help teachers explain the topics related to the exhibit themes. When students come to the museum, they go through six different galleries with well-prepared docents. After the trips, students participate in follow-up activities in the classroom. For example, this year the main exhibit in the museum is the "Victorian Fairy Paintings." An educator wants to continue the theme from the exhibit visit to the activity during her class. She makes up a story in which a fairy journeys to the museum. The students are 
expected to create an artwork which reflects the story. These activities help children continue to build knowledge on the experiences from the field trips.

In addition to the structured activities regarding visits, the well-selected content of the program and the support of well-trained docents are extremely important for a quality visit. The University of lowa Museum of Art considers these factors in a thoughtful manner. The exhibits are not necessarily targeted for the third-graders, but, they are presented in friendly approaches to this group of viewers. Many supplemental visual materials are provided during tours such as pictures of artists, a map of Africa, a real bird's nest and real materials for printmaking. One unique aspect of the visual materials is a video about a living artist in the community who currently exhibits his work. This year the video featured an interview with an emeritus professor in the Art Department of The University of lowa. His works incorporate strong pigment colors in geographic patterns. Thus, the theme of his interview was "colors." He showed how he technically makes the patterns in his works. It helps viewers to understand the process of art making while they try to figure out the strokes of the paintings. Children might be receiving the same experience as if they came to his studio. He also explained what he means in his recent works, which convey our history and its symbolic images, including the pyramids, Mickey Mouse and Calvin, characters from cartoons, and more prominent characters in world history. Some characters are familiar to the third graders. These are mentioned during their visits by the children, themselves, with much excitement. This is one evidence that the educator from the museum and the artist himself acknowledged the level of the audience, they tuned the level of interpretation for the students. Since the purpose of the "WOW" Program is to make children accept "museums as life-long resources for learning and enjoyment," as the museum states, the flexible approach to different levels of audience--seeing an artwork through children's eyes in this case-is important in helping them to have fun and encouraging them to come back with friends and parents.

On the practical side, docents are extremely important because they are the ones who literally face visitors. The school visits are usually accompanied by classroom teachers, but mainly implemented by either an educator or docents. Geller ( $p 7$ ) emphasized the importance of teachers' participation in shaping the museum experience of students. However, the observed museum visits didn't show evidence of collaborative efforts between museum educators and classroom teachers. Very few teachers had a chance to remind the students, while they were in front of the materials, of the facts they had learned during their classes. One teacher mentioned that the main characters from one of the Victorian paintings contains the same characters as Shakespeare's "A Midsummer Night's Dream." Thus, docents are the main facilitators of the programs.

Docents have been an important group of people through the history. After World War II, more art museums were built and more education programs were offered. Providing many educational programs means more people need to prepare and facilitate the programs. Unfortunately, most museums face a lack of staff and time for developing programs. Thus, many museums have been relying on their volunteers. Many museums are relying on docents, volunteers, for 
completing museum visits. In 1895, trustees of the Museum of Fine Arts in Boston accepted volunteers from the Twentieth Century Club from Boston for interpreting the process of sculpture casting. These volunteers were called "docents." Regular docent tours began at the Museum of Fine Arts in Boston in 1907 , almost 30 years after the museum had initiated its education program in 1876. They were expected to help "the museum make the significance of its collections clear and interesting to the public and students" (Horn, p. 105). The main purpose of using docents in the museum was to improve the quality of the lives of the visitors (Grinderk \& McCoy, p. 19). In 1978, Newsom and Silver found that $67 \%$ of art museum workers were volunteers.

The University of lowa Museum of Art has a history of 28 years in the docent program. In the University of lowa Museum of Art, docents are putting forth a tremendous effort for this year's "WOW" Program. The 29 docents are signed up for 67 tours. The docents have voluntarily joined the museum. The museum doesn't limit docent's qualifications, so they have diverse backgrounds. The majority of docents are women. Some of them are retired teachers and some have been actively involved in the community. One common interest among them is that they like artworks and museums. They do not necessarily have a strong background in art. Before they lead a tour, they receive an eight-week training program starting in September. The interviewed docent described how learning is a crucial part of docent work. In order to lead a tour, they get information from the training program, general docent meetings and other supplementary seminars and lectures.

Training sessions are mandatory workshops for prospective docents. They meet from September through November on every Monday morning. At those sessions, docents became more knowledgeable about every aspect of museums: behind the exhibits, storage areas, art library, ceramic kiln and so on. The director of the education program takes them through various tours at the museum. Through these tours they became aware of "where things come from, where collections are stored, how they are put together, physical 'hammer, nails and frames,' that sort of thing." Some other days curators come in and each of them explains what she or he is doing and how the work is done. At one meeting, a display director comes in and brings the docents to the back area where he prepares for an exhibit. He explains how he works with other curators, deals with physical assets for exhibition and controls humidity to protect the art works.

The training sessions also helps the docent to develop personal skills for conducting a tour. When she gives a tour, she becomes more than an interpreter of artworks. As a person, she knows how her feelings and attitude could affect other people. The docent we interviewed explained what a docent should be in the following statements:

It (the training session) just made me more comfortable with this. You are coming into a building like this, you are awestruck. It's a solemn building. It's quiet. It's carpeted. You realize that you are in the place that is a little bit formal. Well, that's O.K. But the person who is doing the tour has to feel, "I know where I am. I know where the bathrooms 
are. I know that the guards are very concerned about certain things." If there is an emergency, I should know how to get my tour out. In other words, I protect. It's a certain amount of ownership. I am part of the team.

At the end of the training sessions, each docent is supposed to do a mockup tour for fifteen minutes in order to "graduate". Each docent chooses their tour groups and their objectives for a visit and pretends to give a tour in front of other people who also pretend to be visitors for other docents. Everything about the mockup tour is hypothetical.

After the formal training, docents have more training sessions for their tours on Mondays from January through March. Docent meetings, which are held every other Monday, provide two things. First, docents get to know each other and exchange ideas, and second, docents learn about current and upcoming exhibits. At the beginning of each meeting, they all talk about recent trips to other cities or other museums, and then everyone makes their own observations. Then either the Education Program Coordinator or one of the curators gives an orientation on a specific exhibit. This is for docents to learn about exhibits, whether they are going to give a tour or not. They all have a walking tour in the exhibits. Folding stools are available so that they can sit down at some point and take notes on what curators are saying. At this time, docents interpret their listening with questions which will help their tours later. This is an interesting point. This process allows docents to use their creativity in terms of interpreting and organizing the information and conveying the information. If every docent did a tour in the same way, that would be too linear and not interesting to tour groups.

The educational role of the museum is not limited to a job for a museum educator. Education has been approached through all the departments and achieved through their collaboration. So, education becomes an institution-wide commitment rather than a specific program for any participant (Excellence and Equity, p. 19). Many educators agree to work with curators for educational program development. Linda Downs (Insights, p. 103) recommends multiple informal discussions while developing an exhibit and subsequent program. The validation from the directors and curators seems to be helpful for achieving quality in programs.

When the educator at the Museum of lowa prepared a teacher's guide for school field trips, she received information from the curators who planned the gallery exhibits. For training docents, support from curators is extremely important and necessary. Two curators came to the docent meetings we observed and gave lectures on the exhibits. This demonstrates good evidence that there is a strong relationship among staff in this museum. During the meetings, the curators raised issues which could be effective with or relevant to third-graders, the expected tour groups. Wendler states that docents are required to keep the correct information, which is received from the training, instead of creating their own interpretation (p. 100). Thus, guidance from staff who have more knowledge on exhibits is important. Multiple observations also proved that many docents delivered similar comments from the staff to students. 
One curator explained her knowledge in "African Mask Exhibitions" which she organized. She emphasized the importance of the context of the African masks. "Contextualist" perspective (Lind 35), which emphasized that an art piece is expected to be understood within its context, is desired in coming society. This approach encourages students to read the ideas and themes which are embedded in the exhibits. The curator mentioned that masks are only a part of the whole costumes for a ceremony. Actually, there was one display which consisted of a mask and a whole wardrobe which was made of African fabrics. The curator had spent a couple months in one of the African communities which used the same kind of special dying and weaving process. The curator had already explained the processes with slides and real fabric samples in one "Wednesday Lecture Series." The African Mask Exhibition only filled a small room of the Museum, however the information inherited in those objects is immense and refers to various kinds of areas. It helps docents better understand the exhibit and the objects.

The other curator talked about the "Victorian Fairy Paintings." She recommended making a connection between the paintings and literature, "Midsummer Night's Dream" and "Peter Pan." The exhibits contained interesting pieces such as paintings developed from book illustration and theater sets. The docents were encouraged to mention stories about paintings, which would help students to imagine situations from the paintings.

In spite of their small number, docents are special people who want to come and learn about museums and exhibits among community members. Supporting this group is also one of the educational missions of museums. Docents, themselves, put forth tremendous effort to complete their role as a translator of knowledge about the artworks and inspirer of ideas which each visit or could generate during and after visits. Thus, how docents prepare for their work is beneficial to not only visitors, but also themselves. While they are preparing they become more knowledgeable about the exhibits. Often they find different perspectives for a certain object, an artist, or a movement and then become more flexible in their interpretation. One docent whom I interviewed, Kelly (a pseudonym), states, "I get intellectual stimulation, exposure to artworks that I couldn't see if I were not a docent." Kelly also reports that she has a changed perspective about modern art. Influenced by her anti-modernist father and his colleagues, she still doesn't like modern art, but she can see the inherent structure and find meaning in the artworks. It is a really challenging process for her, but she has been forced to change because she also wants to feel comfortable enough to share her knowledge with her tour groups.

Since docents are provided more materials than they could present in limited time, they usually develop their own style of interpreting the materials. One docent lead students to large space before the planned tour, "Various kinds of containers, ceramics," started. She brought pots and a ceramic bowl from home and put them on the floor. She explained to me that she wanted children to have the experience of feeling the ceramics before the tour. While they prepare for tours, it's important what kinds of objectives docents have and that they actually perform before groups in ways which are consistent with educators. 
Kelly showed how she understands well what children can go through when they come to a museum. She is aware of what they know and what they expect. "The other overall objective is to get them to be interested in art and come to the museum as a place that has something to enjoy. ... The teachers have prepared their kids in terms of what they are going to see, and the Education Program Coordinator even sent out a slide show as a preview. But by the time you get them in the museum, they have been in the bus, they have ridden and are excited and then take their coats off. Somebody probably pushed somebody else. Somebody has to go to the bathroom. They are typical children, somewhat out of control. However, some of them are, well, perfect angels." When educators and docents prepare visitors this well, it is effective to bring more people and provide meaningful experiences.

Sometimes, some students show behavioral problems while they are in a group tour. They could touch things or ask embarrassing questions for improper purposes, so that they eventually could ruin other students' whole experience at museums. Docents are expected to have the communication skills to manage a group, in addition to being able to talk about the artworks. The interviewed docent heard about one incident, which happened to another docent, from the guard who witnessed the whole thing. One group was not cooperating with the docent's interpretation at all, so finally the docent called them back to a place in a museum that was somewhat separate from the display areas. The students were reminded of the proper attitude inside the museum. After listening to the docent's lesson, the students behaved well and paid attention to what the docent was saying.

Financial difficulties of many museums are another important factor for arranging education programs. Most museums are having a hard time in finding their financial support. Often fundraising is one of the tasks for museum staff in smaller museums. For the "WOW" Program, the museum receives support from a local bank. During the opening week of the fairy exhibit, the museum earned some money which will go for the new Museum Education Resource Center which will open soon with excellent educational facilities. Using volunteers is a way to reduce paid staff members. There is one thing educators need to remind themselves regarding this benefit. Because docents are taking an important role in implementing museum tours, it is often forgotten that they are helping the Education Department. They are not fully responsible for the quality of education programs.

Beginning with September through October, the Education Program Coordinator brings a big calendar to meetings. Then she gets requests for tours. This allows docents to sign-up for tours in advance. Most of the tour groups need more than one docent. So, the Education Program Coordinator arranges the time and place for each docent and makes a master switching schedule which each docent gets and follows. The interviewed docent told us that she has a busy schedule, so when she decides to have a tour, her available time is the primary factor. She admitted that this work is not her only interest at present. "...At this point in my life I just don't give my whole free time to the museum. I just do it when I am available." 
Docents are resources where educators get responses about museums. Interviewed docents reported that they often give advices to the educator. The advices vary from the one directly related to tours to the one for administrative aspects of the museum.

\section{Conclusion}

Museums are places where various kinds of activities happen. One of the major activities is their education programs. In order to implement these, Curators of Education either initiate or develop ideas for activities and interesting learning experiences. Many researchers and museum educators believe that a visit to a museum does not mean anything to students if there is no proper guidance during the visit and in follow-up classes. Hence, better education programs at museums are necessary. The process of development often requires collaboration with other staff members at museums, like curators, security personnel, educators from other institutions, teachers from the local schools, students and many more.

Docents are an effective resource for facilitating education programs. Well-trained docents increase the favorable consensus among the general public and help visitors learn more about the program and have a meaningful experience. It was found that they try to hit the high points and create interaction with their audience during the tours.

Museums have several issues to investigate in the future. One of them is examining quality of content in learning experiences. After the trend which emphasized more interactions between exhibits and visitors, the focus on the display techniques has been tremendously increased. However, the most important thing is what the exhibit is telling individuals. Evaluation methods also could be utilized for education programs. Before implementing programs, the responses from the teachers could be gathered. After each field trip or a lecture, or a class, reactions from the participants about the plans of education programs could be collected in various ways. Some educators often send questionnaires to the teachers after their tours of museums. Some visitors could be interviewed about their learning, feelings, problems, and any other reactions to the programs. This could be a kind of focus group evaluation. Alan Newman (1981) stated that the effectiveness and worth of the focus group research method is that it provides meaningful insights into the attitudes, values and opinions of the visitors (Newman, p. 114). The product, an education program, is supposed to be meaningful, interesting, and enjoyable. The programs need constant revisions and improvements.

Museums should provide meaningful learning experience. The education program development process is not linear. It is a constant process and has multiple stages. Since museums are becoming powerful cultural centers, more careful and prudent attitudes about the content of their programs are required. Museums should be places where people can challenge ideas and inspire each other. 


\section{References}

American Association of Museums. Excellence and Equity: Education and the Public Dimension of Museums. Baltimore, Maryland: Collins Lithographing, Inc. 1992.

American Association of Museums. Museums in the Life of a City: Strategies for Community Partnerships. American Association of Museums. 1995.

Dobbs, S. M. "Dana and Kent and Early Museum Education." Museum News 50. 2 (1971): 38-41

Eisner, Elliot W. \& Dobbs, Stephen M. The Uncertain Profession: Observations on the State of Museum Education in Twenty American Art Museums:- A Report to the J. Paul Getty Center for Education in the Arts. 1984.

Gottfried, J. Do Children Learn on School Field Trips? Curator 23.3 (1979): 165174.

Glaser, Jane, R. "USA Museums in Context." The American Museum Experience: In Search of Excellence. Edinburgh: Scottish Museums Council. 1986: 7-26.

Grinder, A. L. \& McCoy, E. S. The Good Guide: A Sourcebook for Interpreters, Docents, and Tour Guides. Scottsdale, AZ: Ironwood Publishing, 1985.

Hamilton, G. H. Education and Scholarship in the American Museum. On Understanding Art Museums. Englewood Cliffs, NJ: Prentice-Hall, 1978: 98-130.

Horn, A. L. A Comparative Study of Two Methods of Conducting Docent Tours in Art Museums. Curators 23. 2 (1978): 105-117.

Institute of Museum Services. National Need Assessment of Small, Emerging, Minority and Rural Museums in the United States. 1992.

Liind, M. "Reinventing the Museum." Public Interest. 22-39.

McGrath, K. M. “Tax Reform Act of 1969.” Museum News 48. 6 (1970): 29-30.

Mayer, M. M. "Can Philosophical Change Take Hold in the American Art Museum?" Art Education 51.2 (1998): 15-19.

Ramsey, G. F. Educational Work in Museums of the United States. New York: The H. W. Wilson Company, 1938. 
Rawlins, K. "Educational Metamorphosis of the American Museum." Studies in Art Education 20. 1 (1978): 4-17.

Taylor, J. "The Art Museum in the United States." In the American Assembly, Columbia University (Ed.), On Understanding Art Museums.

Englewood Cliffs, NJ: Prentice-Hall, 1978.

Turner, R., Ed. The Grants Register 1975-1977. New York: St. Martin's, 1977.

Weil, S. E. Rethinking the Museum. Washington, D.C.: The Smithsonian Institution, 1990.

Wittlin, A. S. In Search of a Usable Future. Cambridge, Massachusetts, and London, England: The MIT Press, 1970.
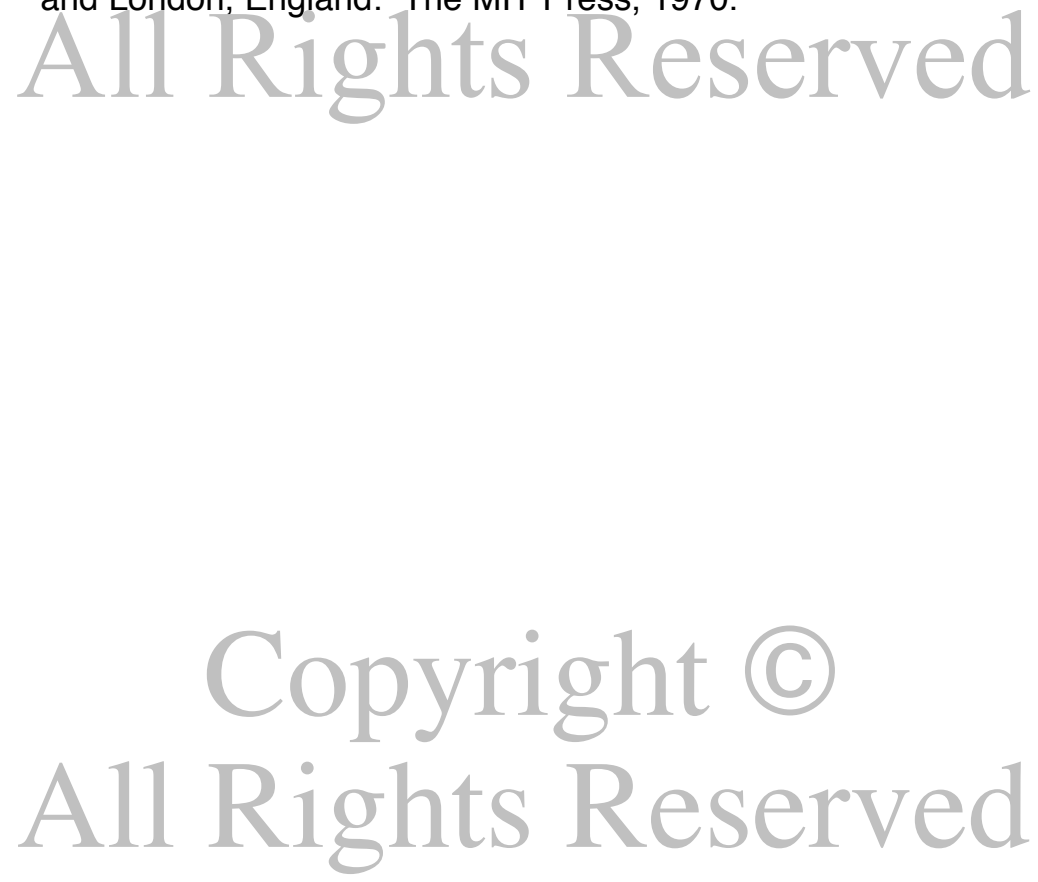